\title{
Making concessions: \\ Political, commercial and regulatory tensions in accounting for European roads PPPs
}

\author{
Stafford, $A^{*}$, Acerete, J.B.** and Stapleton, $\mathrm{P}^{*}$ \\ *University of Manchester (United Kingdom) \\ **University of Zaragoza (Spain)
}

March 2010

Address for correspondence:

Dr. Anne Stafford

M44 Crawford House

Manchester Business School

Booth Street West

Manchester M15 6PB

Tel: 01612750439

Email: anne.stafford@mbs.ac.uk

\section{Acknowledgements}

This study has been carried out with the financial support of the Spanish National R\&D Plan through research project SEJ2004-0791-ECON, Programme Europe XXI for Research Stays supported by DGA (CONSI+D) and CAI, and The Institute of Chartered Accountants of Scotland. The authors gratefully acknowledge assistance from Peter Macdonald and Jean Shaoul.

Paper accepted for publication by Accounting and Business Research 


\title{
Making concessions: political, commercial and regulatory tensions in accounting for European roads PPPs
}

\begin{abstract}
Governments increasingly use private finance to fund roads infrastructure. In particular the European Commission has promoted the use of public private partnerships (PPPs) to deliver the projects forming the trans-European Network. This use of private finance raises important questions about how public monies and assets are accounted for.

The paper examines, firstly, accounting in both public and private sectors for roads PPPs in Spain and the UK, countries which not only have considerable experience in the use of private finance for the provision of roads but also act as exemplars of a number of differences which may be significant from an international perspective in terms of financial reporting and economic outcomes. Secondly, it examines the tensions between national, European Union and international accounting pronouncements.

Our findings suggest that the business environment has influenced the development of accounting policy. In Spain a powerful toll sector presence within the legal framework has led to substantial variations, having real economic impact. In the UK, the accounting regulator has prevailed over political concerns. For European public sector accounting, conflict remains between political choice and technical accounting. These findings may have global relevance, as the adoption of international accounting pronouncements will not remove these conflicts.
\end{abstract}

Key Words: IFRIC 12, Public Private Partnerships, off balance sheet accounting, public sector accounting 


\section{Making concessions: political, commercial and regulatory tensions in accounting for European roads PPPs}

\section{Introduction}

The provision of transport infrastructure, such as roads, bridges, airports and rail, calls for significant funding, especially to cover the construction costs. Such funding can be raised either through government taxation or through the use of private finance. Lack of public funds forced Spain to use private finance in the 1960s with the building of toll roads through concessions. Since then there has been further use of private finance to develop roads as part of public sector reform. The UK has been a world leader in the development of the public private partnership (PPP) model for building and maintaining infrastructure. In the UK one form of PPP is the Private Finance Initiative (PFI). PFI is one form of commonly used terminology, but roads schemes are often referred to as Design Build Finance and Operate (DBFO). For sake of clarity in an international context this paper uses the designation PPP throughout. These roads schemes, paid for by the UK government, using a volume-based shadow toll payment mechanism to avoid politically sensitive direct tolling, commenced in the 1990s.

The structural form of PPP has been copied internationally, and is encouraged by transnational organisations, such as the Organization for Economic Co-operation and Development (OECD) and the World Bank, as a way for emerging and developing countries to establish the infrastructure needed to bring about economic growth. In particular, the European Union (EU) promotes the use of PPPs to deliver the projects that form part of the trans-European Transport Network (referred to as TEN-T), ${ }^{1}$. However, in their three reports 'The trans-European transport network: from aspiration to reality', 'Developing Public Private Partnership in New Europe' and 'Delivering the 
PPP promise: a review of PPP issues and activities (PwC, 2004a, 2004b, 2005) PricewaterhouseCoopers $(\mathrm{PwC})$ argue that, despite the enormous significance of TEN-T to economic growth in the EU and to the achievement of integration goals, progress on delivery of TEN-T has been slow. This they attribute to a variety of economic, legal, political and accounting reasons. Since TEN-T is compounded by many cross-border projects, harmonisation of regulations between countries can reinforce the use of PPP. Of particular relevance to this paper, $\mathrm{PwC}$ argue $(\mathrm{PwC}, 2004 \mathrm{~b}: 10,18)$ that the use of PPP has been hampered by general uncertainty about the accounting regulations in relation to the recognition of assets and liabilities on the public sector balance sheet and guarantees given by government to private sector suppliers. There is thus pressure from a major international player to re-consider the accounting, and other regulations, so that the use of PPPs can be made more attractive to procurers, especially the private sector partners.

By way of contrast this paper focuses on accounting to users and taxpayers. It seeks to determine whether the financial reporting, and hence transparency, of such schemes delivers accountability to users and taxpayers.

The use of private finance raises important questions about how public monies and assets are accounted for, because the PPP mechanism may place considerable government spending in the hands of the private sector. PPPs have been described as blurring the boundaries between public and private sectors (Broadbent and Laughlin, 2003). This is evident in relation to accountability because information, needed to hold decision-makers to account for the use of public money and stewardship of assets, is found not only in the public sector accounts but also in the financial statements of

\footnotetext{
${ }^{1}$ TEN-T is an European Commission policy objective to establish a single multimodal network to integrate transport networks (including roads, rail, air, sea and inland waterways) across member states to
} 
private sector companies (Edwards et al., 2004). Furthermore, while internationally some governments have chosen to adopt private sector accounting policies and practices for public sector accounting, there have been concerns about whether this provides adequate accountability to taxpayers and citizens (Newberry and Pallot, 2003; English and Guthrie, 2003). These initiatives are eliminating the traditional channels of accountability that guarantee the protection of public service users (Torres et al., 2003).

Thus, the use of private finance in public infrastructure raises questions about the extent to which the existing forms of reporting provide useful information about public resource allocation, the evaluation of the policy and individual projects, and future investment plans. Furthermore it requires the examination of financial statements produced by not just the public sector but also the private sector partners.

These accounting and accountability questions are important for a number of interrelated reasons. Firstly, the enthusiasm of both governments and trans-national organisations for the use of private finance means, as we show in the next section, that the scale is substantial and is set to increase. Secondly, capital intensive investment such as road construction projects usually require some public contribution and arrangements that blur the line between public and private entities and activities and/or create government-sanctioned private entities that are near-monopolies. Thirdly, despite the scale of private finance in roads and the blurring of the line between the public and private sectors, there is little public discussion about its use in roads compared to other sectors such as healthcare and education, and this is reflected in a surprising lack of financial analysis or even financial information in the public domain.

ensure the safe and efficient movement of people and goods throughout the EU. 
We examine the accounting and accountability of these PPP roads schemes through an analysis of the main accounting issues raised in the literature and in official reports, as well as through study of publicly available information, and consider the impacts any differences may have. As the accounting and accountability of PPP road schemes is not a single country issue but a wider phenomenon, our research method is to carry out a comparative analysis of accounting treatment of public and private sector partners from two European countries, Spain and the UK, whose public sectors are major players in the sector. Spain and the UK not only have considerable experience in the use of private finance for the provision of roads, but also act as exemplars of a number of differences which may be significant from an international perspective in terms of financial reporting and economic outcomes. The period of our study is in Spain from 1995 to 2007 and the UK from inception in 1997 to 2004, to cover the periods when there were major changes in accounting policy. In addition, given that public sector accounting in both Spain and the UK is governed by EU regulation as laid down in the European System of Accounting (Eurostat, 1995), we examine the Eurostat (2004) pronouncement on PPPs, as well as international accounting regulation in the form of the development of IFRIC 12 Service Concession Agreements (IASB, 2006a).

In this paper we provide evidence and analysis of how the use of private finance is reported in different countries. In a previous paper (Acerete et al., 2009) we showed that the cost of private finance in Spain in relation to tolls roads was nearly twice the cost of public finance, with more than half of the toll charge representing the cost of finance.

The paper is organised as follows. Section 2 sets out the history and development of private road concessions in Spain and the UK. Section 3 describes the research objectives and methods. Section 4 presents our analysis of the accounting treatment. 
Section 5 draws out the implications of different accounting treatments in these two countries and section 6 offers our conclusions regarding the impact on the international position.

\section{Background to private finance in the roads sector}

The involvement of private sector companies in the provision of infrastructure and related maintenance services in the roads sector often takes the form of public private partnerships (PPP). Although there is no agreed definition of a PPP, the essential features are that the private sector provides the finance and the public sector becomes procurer, as opposed to provider, of services.

Although it is widely recognised that it is difficult to achieve policy transfer across countries, PPPs in infrastructure (including roads, rail, water and buildings) have been promoted by multi-lateral agencies such as the World Bank, which has encouraged their use since the early 1990s (World Bank, 1994). There has been the greatest uptake in roads, with the regions of Europe, Mexico and Latin America, and Asia having significant numbers of ongoing projects (Public Works Financing, 2008).

The PPP policy has not been without its problems in practice. An extreme example of failure has been the government bail out in 1997 of the Mexican toll road programme at an estimated cost of US\$7-12 billion (Guasch et al., 2005: 5) but in Latin America as a whole many projects have been taken over or at the very least renegotiated by governments (Guasch, 2004). In East Asia the partnerships aspect of the relationship has been tested as the private sector acted rapidly to halt contract negotiation when the macroenvironment conditions turned against them as a result of the financial crisis of 1998 (Estache, 2001: 90). In Australia the case of the Melbourne City Link road shows 
that taxpayers are paying a high price whilst risk transfer remains unclear (Hodge, 2004). Despite these problems, the Public Works Financing (2008) database shows that planned worldwide spending on infrastructure of $\$ 1,188$ billion is double that funded from 1985 to 2008 , with the roads share being $\$ 580$ billion.

The European position is complex due to the different decisions adopted by different countries, but the European Union's policy has been to encourage the use of PPP in general (EC 2003a, 2004), and Europe has the biggest percentage of global planned and funded projects in terms of value (Public Works Financing, 2008). The European Commission (EC 1997, 2001, 2003b) has been especially interested in the use of PPP as a means of speeding up the delivery of the infrastructure projects that form part of TENT since the scale of the required investment is very large.

\subsection{Roads concessions in Spain}

Spain was an early user of private finance for public projects, especially in the roads sector. Its toll road programme began in 1967 with the publication of a plan to construct $3,160 \mathrm{~km}$ of new highways ${ }^{2}$. This was earlier than in the UK and the rest of the EU due to the smaller size of the Spanish public sector from the 1950s to the 1970s (Torres and Pina, 2001). While France and Italy decided to fund road construction through user tolls rather than taxation and operate the roads via public bodies, Spain offered contracts to the private sector to build, finance, and operate some of the roads. It also offered the right to charge vehicles to use the roads (Farrell, 1997). The revenue stream accrued to the concessionaires (Bel and Fageda, 2005).

\footnotetext{
${ }^{2}$ Programa de Autopistas Nacionales de Peaje 1968-1979 (National Programme of Toll Highways 19681979).
} 
The private roads did, however, incur government cost. Bel and Fageda (2005) claimed that the financial, fiscal, and commercial conditions of the franchises were such that almost every risk was borne by the government. In particular, it provided state-backed guarantees for foreign loans and exchange rate insurance against any increase in the cost of finance raised by international loans, thereby reducing the concessionaires' exchange rate risk (Izquierdo, 1997). Several of the toll roads had higher costs, in part because of the high construction costs and the additional costs associated with tolling, and carried less traffic than anticipated, since many motorists preferred to use the free roads. As a result, despite the expansion in 1972 of the plans for $6,340 \mathrm{~km}$ of new road construction, by 1985 only $3,000 \mathrm{~km}$ were open to traffic ${ }^{3}$. Of this, some $1,800 \mathrm{~km}$ were private sector toll roads, mostly in the Mediterranean corridor and the Ebro Valley connecting the areas of highest economic growth (Bel and Fageda, 2005). They were concentrated where there was the highest expected profitability. Spain's economic and exchange rate crisis of the 1970 s and early 1980 s further undermined the financial viability of the concessions, and they were either taken into public ownership or renegotiated (Engel et al., 2002).

In 1982, the incoming Socialist Party government reverted to a programme of road building based upon conventional public procurement, contingent upon economic expansion, increased tax revenues and, after 1985, funding from the European Commission (Izquierdo and Vassallo, 2004). However some of the regional authorities did award toll road concessions to the private sector in this period. Subsequently the adoption of the Maastricht criteria that constrained public expenditure based on debt financing led the new Conservative Government firstly to pass a law ${ }^{4}$ in 1996 that

\footnotetext{
${ }^{3}$ According to data included in annual reports of the Ministry of Public Works (Ministerio de Fomento, various years).

${ }^{4}$ Later Ley 13/2003 Reguladora del Contrato de Concesion de Obras Publicas established a maximum period of 40 years.
} 
included provisions to enable concessions of up to 75 years. thus facilitating a return to private financing of toll roads. Secondly, the new government renegotiated extensions to the existing agreements without entering into competitive bidding or receiving payment from the concessionaires in return for reducing toll charges by $30-40 \%$ and some additional investment. Thirdly, it announced a 1,210 km highway construction for completion by 2010, and in so doing acknowledged that many of the new toll franchises required huge public subsidies due to low traffic projections ${ }^{5}$. Bel and Fageda (2005) cited Izquierdo (1997), who claimed that half of the projected highways in the first phase of the programme required subsidies ranging from $40-65 \%$ of the total investment.

Toll highways are governed by statute and fall within the remit of the Ministry of Public Works, which is responsible for public works and transportation, but is not a specific regulatory body. Bel and Fageda (2005) state that prices were set at the financial close and have since been renegotiated on an individual basis. They are also subject to a formula for yearly price adjustments based on the retail price index that takes no account of quality of service, maintenance, or additional lanes ${ }^{6}$. With strong traffic growth in the late 1990s, profits rose and in 2001 in response to public pressure, the formula was amended to include traffic volumes and a cap as a way of sharing 'excess profits'. Since then charges have risen by $3 \%$ or more a year ${ }^{7}$. Concessions awarded before 1988 are less constrained by price cap regulation, and Albalate and Bel (2009) find that in the case of the two oldest concessions, the increase in traffic volume has led to user overpayment and increased company profits.

\footnotetext{
${ }^{5}$ Programa de Autopistas de Peaje 1997-2000 (Toll Highways Program 1997-2000).

${ }^{6}$ Real Decreto 210/1990, sobre el procedimiento de revision de tarifas de autopistas de peaje (Royal Decree 210/1990, procedure for revision of toll highways tariffs).
} 
In addition to private sector toll roads, in the late 1990s, the autonomous regions of Madrid and Murcia (and later several others) also entered into contracts with the private sector to build finance and operate five roads. Interestingly, despite a history of direct tolling going back to 1967 , these were funded by the tax payer on the basis of shadow tolls, mimicking the UK payment system (Pina et al., 2003), thus enabling necessary improvements to the road network required for economic growth without either contravening the Maastricht criteria or imposing unpopular new direct tolls on the motoring public (Benito et al., 2008). The tariffs were set out in the contract, but were not put in the public domain, nor made subject to the formula for annual adjustments applicable to the other post 1988 private toll roads.

By the end of 2007, the last year in which pre-IAS/IFRS accounting treatment was applied, some 2,780 km of private toll highways (see Table 1), $465 \mathrm{~km}$ of shadow toll highways (see Table 2) and 10,040 km of free highways were in operation in Spain.

Insert Tables 1 and 2 about here

The use of private finance in this way is set to continue. The Spanish Strategic Plan for Transport Infrastructure ${ }^{8}$ is an ambitious plan involving forecast investment of 248,892 million euros for the period 2005-2020. On its approval, the Minister of Public Works said that some $20 \%$ of this amount should come from private financing ${ }^{9}$. Whilst

\footnotetext{
${ }^{7}$ Art. 77, Ley 14/2000, de medidas fiscales, administrativas y de orden social (Law 14/2000, fiscal, administrative and social issues).

${ }^{8}$ Plan Estratégico de Infraestructuras de Transporte, PEIT

${ }^{9}$ Ministerio de Fomento (2004), Plan Estratégico de Infraestructuras de Transporte 2005-2020 (Ministry of Public Works: Strategic Plan for Transport Infrastructure 2005-2020s).
} 
railways were due to get the largest share, the roads sector was second with a package of some $62,785 \mathrm{~m}$ euros.

Furthermore, Spain has become a major international construction player. Its long tradition and experience of concessions in the roads and wider infrastructure sector has been exported to countries all over the world (Albalate et al., 2009). Six out of the top seven transportation developers in 2008 were Spanish, operating 103 (29\%) out of the top 355 concessions over \$50m capital in the world (Public Works Financing, 2008).

\subsection{Road concessions in the UK}

The first private finance infrastructure projects in the UK in the 1980s were for new builds: the Dartford Bridge, the second Severn Bridge, the Skye Bridge and the Birmingham North Relief Road. These projects involved tolling, which the government of that time wanted to extend to improving and maintaining existing roads, outlining its proposals in its Green Paper 'Paying for Better Motorways' (DoT, 1993) and 'Design, Build, Finance and Operate Concessions for Trunk Roads and Motorways' (DoT, 1994). Under these schemes the private sector would be invited to extend or enhance a road and then operate and maintain it and a further stretch of road for a 30year period. The 30-year period was chosen because the payment mechanism had to enable the debt finance, which typically has a repayment period of 20 years, to be repaid and ensure a return to the equity investors. Payment would be via a shadow toll system based on the number of vehicle kilometres travelled, which would be capped at a certain level.

Of the 10 proposed PPPs announced in 1994, eight went ahead in 1996-7, albeit some in a slightly different form than originally announced (see Table 3). The construction value of these eight projects signed by the Highways Agency for roads in England in 1996 
was substantial, at about $£ 590 \mathrm{~m}$, and accounted for about $35 \%$ of all new road construction projects between 1996 and 2001 (DTI, 2003).

Insert Table 3 about here

The UK government's intention, outlined in its national 10-year transport plan, 'Transport 2010' (DETR, 2000) was to continue the use of private finance. This plan allocated $£ 21$ bn to the strategic highway network, $25 \%$ of which would involve private finance. However, after the first tranche of eight projects, only a small number of further schemes had reached financial close by 2008 (see Table 3).

\section{Research objectives and method}

It has long been recognised that transferring accounting regulations and practice between countries is problematic. Differences in financial reporting persist even after formal or de jure standardisation of regulations has occurred (Chen et al., 2002), because practice is influenced by the environment in which it is embedded and by the ends it is expected to serve (Choi and Mueller, 1992; Peasnell, 1993).

While both Spain and the UK are important players in the roads industry, their regulatory accounting environments differ, as summarised in Table 4. The UK has a common law system and an independent accounting regulatory system that established, prior to the adoption of IFRS, standards for financial reporting, and a strong equity capital market, which La Porta et al. (1997) find is associated with strong investor protection. The UK is an example of a country that has separate laws for tax and accounting (Lamb et al., 1998), with the implication that taxation rules do not determine accounting measurement. 
Insert Table 4 about here

Spain is a typical code-law regime (Arnedo et al., 2008), with a government-driven and tax-dominated system. Financial reporting is plan-based ${ }^{10}$. The financing system is credit- and insider-dominated, associated with strong legal protection for creditors (La Porta et al., 1997).

We take a qualitative analytical approach in order to examine the influences on the development of accounting regulation for PPPs. Our comments on the development of financial reporting in Spain are based on the period from 1995 - 2007 to cover changes in policy and accounting for this sector, as will be explained in a subsequent section. We qualitatively examine the financial reporting by 33 private toll road concessions run by 24 concessionaires (Table 1) and fifteen concessions that are paid for by Spanish autonomous governments on the basis of shadow tolls (Table 2). For comparability, in the UK we examine the reporting of the first eight projects signed by the Highways Agency, for eight years from their inception in 1997 to 2004, to cover the period when there was a major change in accounting policy. As financial analysis databases such as Amadeus and Thomson One Banker do not provide enough information to enable detailed qualitative analysis of accounting treatment, we obtained copies of the financial report and accounts of the road operating companies and public sector organisations, either directly from the organisation or from the relevant national registrar of companies. Our qualitative analysis therefore relies on the additional information provided on accounting treatment in the notes to the accounts.

\footnotetext{
${ }^{10}<$ http://iasplus.com/country/spain.htm $>$, accessed February $15^{\text {th }} 2010$.
} 
In addition, we examine the EU requirements for national accounting and the adoption of IFRS and show the difficulties in applying IFRS on a European-wide basis across different national accounting regimes. Further evidence is provided from official reports, accounting regulations and other commentaries.

\section{Accounting for PPPs - Empirical Evidence}

In this section we give our findings on the practices of reporting of PPPs in Spain and in the UK, based on our examination of the financial statements of the concessionaires and the public sector bodies. In addition we examine the developments at an international level as they impact European Union countries. In these sections we also draw on accounting issues highlighted by the $\mathrm{PwC}$ reports (PwC, 2004a and b) as well as a number of issues about the practice of reporting identified by Edwards et al., (2004) and Shaoul et al., (2008). We show that there is a further layer of complexity beyond the broad issues raised by $\mathrm{PwC}$ which is only revealed by detailed study of the actual accounting treatment as disclosed in the notes to the accounts.

\subsection{Accounting for PPPs in Spain}

This section considers the issues arising in accounting for toll roads, where the analysis identifies two unusual accounting treatments. There are also issues surrounding: the use of revaluation of assets; accounting for shadow toll roads; and the reporting of accounting concessions made by the government in support for the industry such as the treatment of guarantees and the shift from lending to profit sharing.

Toll roads have been operational since the 1960s. Over this period legal variations to the accounting regulations have been instigated in order to reflect the specificities of the toll road sector and organisations have been created to promote the interests of the 
Spanish infrastructure and construction industry, such as ASETA (Spanish Association of Turnpikes, Tunnels, Bridges and Other Toll Road Concessionaire Companies). In addition, government industrial policy is based on 'promoting national champions' (Albalate et al., 2009: 308). From the outset there has been government assistance in the form of guarantees and loans. Although there has been little debate over the appropriate accounting treatment to apply, we show that the accounting treatments that have been developed bring real economic benefit for concessionaires.

As stated earlier, Spain's accounting regulations stem from a code-law regime where the emphasis is placed on the legal and tax implications, rather than on the economic substance of the transaction as is the case in the UK. We show this comparison of accounting treatment, together with the ensuing accounting debate and resultant regulations in Table 5. In terms of accounting for PPPs, central government accounting follows the General Chart of Accounts issued in 1994 (Benito et al., 2003). Usually full accrual accounting is used, although Montesinos and Vela (2000) note there are important exceptions. For example, government capital assets, when acquired or created for direct public use by citizens, are recognised as capital investments during construction and are written off (expensed) immediately on completion. This applies to infrastructure assets amongst others. The fact that depreciation is not recognised makes it difficult to determine costs, operating result and impact on equity.

Insert Table 5 about here

Spanish accounting for private sector entities is regulated by company law, the Commercial Code, and the Spanish General Accounting Plan, with a new Plan compliant with international accounting standards taking effect in 2008. However, not 
every sector of the economy follows the General Plan precisely. There was early sectoral variation to the General Accounting Plan for toll highway concessionaires in 1977 along with a number of other sectors (Gonzalo and Gallizo, 1992: 78). In 1999 the standard for the toll road sector was revised (ICAC, 1998), introducing two significant regulations: the capitalisation of financial expenses and the allocation of a reversion fund. In addition, infrastructure may be subject to ad hoc revaluations. We examined the concessionaires' financial statements and related notes to the accounts in relation to each of these regulations and discuss the implications of each of these in turn. Our findings from this qualitative analysis are summarised as accounting issues with associated accountability consequences in Table 5.

Firstly, in relation to the capitalisation of financial expenses, Spanish regulation for toll concessionaires goes much further than in other sectors where financial expenses generated by resources specifically obtained for financing the construction of one asset can be capitalised only during the construction period. For these roads capitalisation can continue even after the project is opened to traffic. If the expenditure is not recorded as additional value in the infrastructure, then it may be shown as deferred expenditure to be recognised as an expense in future years (ICAC, 1998).

The rationale for the deferral of expenditure is that there are long timing differences in the sector between the payment of financial expenses and the receipt of the related operating income (Rojo and Ramírez, 1999). Financial expenses will be high at the beginning of the concession period, due to the high level of indebtedness for financing investments, whilst operating income is expected to increase as the years of the concession go by. In order to comply with the accruals concept, a formula-based approach is used to assess the financial expenses that are to be either recognised in the 
profit and loss account or capitalised, provided that there is reasonable evidence that these expenses can be recovered from future tariffs (Ramírez and Rojo, 2000). The financial expenses recorded in the profit and loss accounts of the Spanish concessionaires do not represent interest payable but are rather a figure calculated by following the requirements of the accounting regulation. Our examination of the notes to the accounts in the concessionaires' annual reports, reported in Table 5, shows that one anomaly with this requirement is that, although it was developed as an accounting treatment for the new concessions, it has been applied by all toll companies, even those running mature concessions where presumably their figure of turnover has reached an optimum level. We regard this as further evidence of the Spanish emphasis on legal form rather than a focus on the substance of the transaction.

The second special requirement of the sector variation is that a reversion fund must be set up. The rationale is that, in theory at least, the concessionaires' main investments will revert to public ownership at the end of the contractual period without any payment in return, i.e. the company will be dissolved at the end of the concession, with shareholders having the right to recover their investments (Rojo and Ramírez, 1999). Therefore, each concessionaire allocates a long-term non-distributable reserve, the reversion fund, that covers the net value of the infrastructure at the end of the concession plus expenses for reverting the asset (ICAC, 1998). Once the road has opened, periodic allocations are made to the reversion fund, calculated in a similar way to the capitalised interest formula (Rojo and Ramírez, 1999). Prior to 1999 only some concessionaires made a provision as it was not compulsory. A change to the regulation in 1999 made setting up a reversion fund compulsory (Rojo and Ramírez, 1999). Allocations to the reversion fund have been significant, accounting for 2 bn euro (44\%) of operating expenditure over the period 1995 to 2003 (Acerete et al., 2009). 
There is only one case, the A-8 Bilbao-Behovia highway, where the concession has terminated, with the relevant highway infrastructure being divided into two stretches managed by new concessions. We examined the financial statements to see how the reversion fund was accounted for on termination. We found that the amount accumulated in the concessionaire's reversion fund was applied to compensate the accounting value of the infrastructure transferred, thus demonstrating that the objective behind the setting up of the reversion fund had been achieved ${ }^{11}$.

The third feature of toll concessionaires' balance sheets is the ad hoc revaluation of infrastructure assets. In the 1970s and 80s revaluation of tangible fixed assets was common because, during times of high inflation, loss-making companies could achieve future tax savings by charging higher depreciation against taxable income (Gonzalo and Gallizo, 1992: 123). Although revaluation and updating of assets were optional, all companies had recourse to these regulations ${ }^{12}$ and they periodically revalued their assets upwards until 1996 since when no further revaluation has been permitted. As a result, at the current time some $40 \%$ of the net value of fixed assets is attributable to revaluation (Acerete et al., 2009).

Shadow tolls are accounted for at present in the same way as direct toll contracts. The government treats them as payments for services provided by operators, that is, as an operating expense. Concession companies treat payments received as operating income, and show the infrastructure costs as depreciating assets on their balance sheets. However the Commission of Accounting and Administration of the Public Sector of the

\footnotetext{
${ }^{11}$ Data obtained from the Balance Sheet of the concessionaire of this toll highway, Europistas (2003).

${ }^{12}$ Regularization Decree-Law 12/1973; Revaluation O.M. 15th March 1976; updating in Laws of Budgets 1979, 1981 and 1983 and Royal Decree-Law 7/1996.
} 
Asociación Española de Contabilidad y Administración de Empresas (AECA), which has the task of issuing documents regarding the recognition, assessment and presentation of items in public sector financial statements, has issued a document (AECA, 2005) developing the treatment of public sector non-financial assets, where it refers to the accounting recognition of infrastructure under PPPs. If, as a result of a shadow toll contract, the public authority assumes the risks and benefits of the contract, the asset should be recognized in the public sector balance sheet, along with a liability for the amounts to be paid when the asset comes into service. AECA (2005) is a document with no compulsory application but, together with other documents issued by the Commission, it confirms a new framework for the evolution of accounting for PPPs in the Spanish public sector, going beyond the established accounting basis. This treatment of shadow tolls is an approximation to the UK's treatment set out in section 4.2 .

We now turn to consider accounting for governmental support for this industry. Here we can differentiate between contracts awarded in the 1960s and 1970s and those awarded in the 1990s and also between direct motorway toll concessions and shadow toll concessions.

For the early concessionaires, due to the lack of national financial resources with which to finance investment in motorways, the Spanish government established an exchange rate scheme whereby it guaranteed foreign currency payments to help concessionaires raise international finance. Our detailed examination of the notes to the accounts, summarised in Table 5, shows that these guarantees were not recorded in the public sector accounts as liabilities. Instead, payments made by the government to private operators were recorded as expenses in the year of payment. These continue for a small 
number of companies. Later concessionaires have been able to raise funds without such explicit guarantees, although the fact that the government has awarded compensation and other direct payments indicates some level of implicit guarantees by the public sector, despite these not being recorded as a contingent liability.

Our examination also shows that the public sector has lent directly to the concessionaires through instruments such as refundable advance payments and participative loans. For example, as a means of initially supporting these investments the Government used 'refundable advance payments'. These are resources given to concessionaires similar to interest free loans, which are repaid when there is an adequate amount of profit. In the most recently awarded contracts, the Government incentivises new concessions by means of 'participative' loans. Here the reimbursement of the loan is normally linked to the amount of turnover, so the Government 'participates' in toll incomes. This method indicates a change in the policy of supporting the toll sector, replacing refundable advance payments. It provides further evidence of the blurring of boundaries between public and private sector, as the public sector moves to participate in profits alongside the private sector (Shaoul et al., 2007). It also provides further proof of the hypothesis advocated by Albalate et al. (2009) that, as the private sector's involvement in public infrastructure grows, the state seeks to increase output regulation. Furthermore, the shift to shadow rather than direct tolling raises questions about political expediency, in that this shift permits government to underreport the debt, and thereby meet the EU convergence criteria (Benito et al., 2008).

In summary, the fact that the Spanish toll sector has been established for a number of decades has meant that accounting treatment has developed to suit its characteristics. It has profited in the past from preferential government treatment e.g. on foreign currency 
guarantees. More recently there has been public sector compensation and other payments being made to toll concessionaires when tariffs have been frozen, and the additional benefits of refundable advance payments and participative loans. Whilst the nature and history of the toll sector in Spain means that the issues of control of and accountability for the infrastructure have not been the subject of widespread debate, there are indications that the move to a shadow tolling system changes how infrastructure assets are viewed. It also raises questions about how to account for public sector infrastructure assets, even though the recognition of risk in the public sector balance sheet is not yet compulsory. Our analysis has highlighted delays in recognizing expenses and transparency failings in relation to government capital assets, as well as issues in relation to accounting for financial expenses, the use of a reversion fund, ad hoc revaluation of assets and the use of government guarantees.

\subsection{Accounting for PPPs in the UK}

The UK as a global player has been instrumental in encouraging the use of PPP internationally and there is consensus that its approach to the accounting issues is the most developed (Grimsey and Lewis, 2004: 154). This section explains the British accounting regulations and then examines how these were applied to the first eight roads projects. A comparison to the Spanish issues is provided in Table 5.

Two accounting standards are potentially relevant to PPP accounting, generating an accounting debate in the UK between two alternative perspectives on the nature of PPP (English and Guthrie, 2003). The first standard is Statement of Standard Accounting Practice (SSAP) 21 Accounting for Leases and Hire Purchase Contracts (ASC, 1984), which distinguishes between operating and finance leases. The second is FRS 5 Reporting the Substance of Transactions (ASB, 1994) which requires the recognition of 
the economic substance rather than the legal form of transactions, and therefore seeks to address the concern of the Accounting Standards Board (ASB - the UK standard-setting body) about inadequate transparency and disclosure of risk in private sector companies by bringing off balance sheet financing back onto balance sheets.

When applied to PPP projects, if a government entity had ownership claims over an asset or long-term liabilities associated with it then the ASB now expected such assets and liabilities to be on the balance sheet of the government body (Baker, 2003). Essentially, in line with SSAP 21 and FRS 5, the ASB argued that PPP is a financing arrangement for the procurement of infrastructure, thus assets and liabilities should be accounted for in the public accounts.

This outcome contrasted with HM Treasury's preference for PPP projects to remain off public sector balance sheets, and it argued that the ASB had misunderstood the nature of PPP arrangements. The Treasury argued that PPP primarily represents the procurement of infrastructure-based services, in which case, the asset and liability would not be recognised in the public accounts (English and Guthrie, 2003). While stressing that it only had authority to determine accounting rules for private sector companies, the ASB added Application note F to FRS 5 (ASB, 1998a), in an attempt to overcome its differences with the Treasury. Recognising that PPP contracts may take various forms the ASB sought to provide guidance that would be sufficiently broad to encompass all these variations but yet would remain clear and unambiguous (Cearns, 1998).

In essence note $\mathrm{F}$ has three purposes. Firstly, it is used to determine whether the public sector purchaser has an asset of the property together with a corresponding liability to pay for it, or alternatively has a contract only for services. Secondly, it is used to 
determine whether the operator has an asset of the property or alternatively a financial asset being a debt due from the purchaser (paragraph $\mathrm{F} 4$ ). As note $\mathrm{F}$ is written these are separate decisions; there is no requirement to identify one or other organisation as having an asset. Thirdly, it is used to determine whether accounting should be governed by SSAP 21 or FRS 5.

While the specifics of these standards vary, both SSAP 21 and FRS 5 base the recognition test on the risks and rewards of ownership. , In the PPP context the risks and rewards that relate to property are often bound up with the risks and rewards of providing the service (Cearns, 1998) so that it may be very difficult to judge where risks and rewards lie. This approach is complex and may give rise to uncertainty about the accounting treatment to be adopted, although paragraph F14 argues that in many cases it will be clear that a finance lease exists. The spirit of this regulation appears to be that PPP infrastructure is likely to be a finance lease, implying that it would be recognised on the public sector balance sheet together with the associated long -term liability.

FRS 5 requires the asset and associated liability to be recognised at fair value if the public sector purchaser has an asset of the property. Fair value implies that the asset be recognized at a market value established between two willing and knowledgeable parties transacting at arm's length. Since such a scenario is extremely unlikely in relation to public highways an alternative is required. In its discussion paper on measurement bases (IASB, 2005) a hierarchy for estimating substitutes for fair value is proposed which would permit the use of models to determine an approximation for fair value. Market based models are preferred but in their absence the discussion paper accepts that current cost or historic cost may act as substitutes or that an entity may use a model depending on entity specific expectations using data not demonstrably 
inconsistent with observable market expectations. Fair value requires the exercise of judgement about the appropriate asset value, which may not improve comparability of accounting or transparency. In addition FRS 5 makes clear (ASB 1998a, paragraph F51) that other obligations are to be accounted for in accordance with FRS 12 Provisions, Contingent Liabilities and Contingent Assets (ASB, 1998b). Contingent liabilities should be reported in a note to the accounts unless there is only a remote possibility that they will fall due.

Edwards et al. (2004) and Shaoul et al. (2008) have provided an analysis of the practice of UK PPP accounting in the roads sector. They raise four reporting issues that are relevant here in our comparative study, showing that a lack of transparency in the reporting of PPPs is an international phenomenon.

First, the potential for asymmetrical reporting that is inherent in FRS 5 has become actual asymmetry of reporting in practice. In the case of the Highways Agency in England, seven out of the first eight contracts were off balance sheet from inception until 1999/2000 with recognition only of intangible assets representing the reversionary interests. As all eight were on private sector balance sheets, there was symmetrical reporting in respect of seven of the eight projects. However, by 2000/2001, the Highways Agency accounting policy changed to show all eight contracts on its balance sheet so that the accounting became asymmetrical for all of the first eight projects. This contrasts with the contracts under UK regional authorities, which continue to be shown off balance sheet. As there is no requirement to disclose details of risk assessment it is not possible to judge how such conflicting conclusions were reached with the implication that the taxpayer is faced with uncertainty about future liabilities (Shaoul et al., 2008). 
Second, UK public authorities, with the exception of the Scottish Government, aggregate actual payments on their DBFO contracts, which makes it impossible to compare actual and expected payments and to consider their impact on affordability.

Third, the complex group structures of the private sector create the possibility of transfer pricing, with profit being recorded in a related party rather than in the accounts of the Special Purpose Vehicle (SPV) the company with which the public sector has contracted. The significance is that such profits cannot be readily identified in the related party accounts. Since they operate as close companies, the SPVs are not required to, and do not, disclose the amount of payments made to related parties (Edwards et al., 2004).

Fourth, despite the fact that the government guarantees the Highways Agency's payments on the contracts (Standard and Poor's, 2003), accounting for such guarantees is not visible in the public sector accounts (Shaoul et al., 2008). Thus, following Note F, the implication is that there has been a determination that the possibility that these guarantees will be called upon is remote. This lack of transparency mirrors the experience of Spain.

In summary, PPPs are relatively new in the UK, and so have been accounted for in the aftermath of the considerable debate around reporting the substance of transactions. Initially accounting regulations followed the private sector principle of substance over form and the specific standard for accounting for leases, but the controversial Note F addition to FRS 5 in 1998 showed that PPPs create separate and problematical 
considerations. The complexity of the private sector companies, and their use of close company status, undermine transparency of reporting.

\subsection{Accounting for PPPs in Europe}

Accounting for PPPs has been recognised as an international problem with interventions from both the IASB and Eurostat, the EU's statistical information service. From the macroeconomic point of view, the interpretation of accounting for PPPs in the European System of Accounts (ESA 95) is problematical for member states (PwC, 2004a) and indeed clarification has been issued by the Committee on Monetary, Financial and Balance of Payments Statistics and by Eurostat (2004) and, from the microeconomic point of view, by the publication of two interpretations by the IASB. The essence of the accounting problem, similar to the UK debate, has been about determining where, if at all, the infrastructure built using PPP and the associated obligation to pay for it are to be recognised. Essentially this debate has focused upon how an asset is defined, rather than on the nature of PPP itself as in the UK, and how the details of a PPP contract are interpreted within that asset definition. However the question of contingent liabilities associated with government guarantees has also been a concern emanating in particular from the World Bank in relation to emerging and developing countries (Shaoul et al., 2008).

Initial international accounting regulation focused on control over and definition of PPP assets and is contained in IAS 17 Leases (IASC, 1997), which classifies leases as either finance or operating leases dependent on the level of transfer of the risks and rewards of ownership. However the complexity of PPP contracts is such that the IASB has made further direct intervention in the form of interpretation SIC 29 Service Concession Agreements (IASB, 2001), which contains disclosure requirements by both private and 
public sector parties of: a description of the arrangement and changes during the period; significant terms that affect the amount, timing and certainty of future cash flows; the nature and extent (meaning quantity, time or amount) of rights and obligations in relation to the assets, the services provided and renewal and termination options. SIC 29 explains that this disclosure is warranted because the IASB's Framework for the Preparation and Presentation of Financial Statements (IASC, 1989) states that users have a right to be able to evaluate the risks associated with future cash flows, and although this is a private sector based rationale the disclosure requirements are also intended to improve the transparency of public sector accounts.

More recently, operator concern about lack of guidance on how to account for PPP infrastructure led to the International Financial Reporting Interpretations Committee (IFRIC) establishing a working group comprising representatives from Australia, France, Spain and the UK. The resulting IFRIC 12 Service Concession Agreements (IASB, 2006a) states that operators should not recognise infrastructure falling within the definition of a service concession agreement, as property, plant and equipment, since the arrangement does not transfer the right to control the use of the public service infrastructure to operators. The infrastructure remains under the public sector entity's control, with the operators acting as service providers. Instead the operators should account for a financial or intangible asset to recognize the benefit of the right to provide services over the life of the contract. The accounting approach under IFRIC 12 is summarized in Table 5. IFRIC 12, unlike FRS 5 note F, makes a distinction between accounting for these assets depending on whether the primary responsibility for payments rests with the public sector, in which case the operator shall recognise a financial asset, or whether payment comes primarily from users, in which case the operator shall recognise an intangible asset. Many of the responses to previous drafts of 
this interpretation were critical of this accounting treatment but IFRIC has confirmed its original decision (IASB, 2006a). Both British and Spanish regulators raised several concerns (ASB, 2005; ICAC, 2005), which, in the Spanish case, were strongly reaffirmed by the association of road concession companies, ASETA (2005).

Firstly, the distinction between the financial and intangible asset for the PPP infrastructure, based on the formal criterion of 'who is the payer?' is insufficient since it does not take into account the economic substance of the transaction. Similar contracts may be accounted for differently, giving rise to a different impact on financial statements through timing differences in the recognition of revenues and expenses. There may be cases where the difference between the models is finely balanced, for example, where payments are made by users, but there are additional payments from the grantor if those fall below a minimum guarantee income.

Secondly, although accounting by the public grantor falls out of the scope of the draft interpretations and asymmetry of reporting still remains, there is a 'rebuttable presumption' (ASB, 2005) implicit therein that assets should be recognised on the public sector balance sheet. Moreover, the implication of failing to prescribe accounting for the concession grantor is that the situation may arise where the infrastructure may be recognized neither in the balance sheet of the operator, nor in the balance sheet of the grantor. In fact the Financial Reporting Advisory Board to HM Treasury (2005) in its response to IFRIC has indicated its belief that one or other entity ought to hold the assets on balance sheet. In this respect, in March 2008 the International Public Sector Accounting Standards Board (IPSASB) issued a Consultation Paper on 'Service Concession Arrangements' (IPSASB, 2008), which focuses on the accounting and financial reporting issues of these arrangements from the perspective of the public 
sector entity, because it is generally the grantor in these arrangements. This considers the principles applied in IFRIC 12. In a similar vein, the UK Treasury has issued guidance for the UK public sector which is largely a mirror presentation of IFRIC 12 (HM Treasury, 2008).

Thirdly, the ASB is critical of the decision that an operator should recognise assets only if it controls their use, since its preference is for a definition based on risks and rewards of ownership, a position rejected by IFRIC 12 on the grounds that this is likely to lead to complexities and inconsistencies. The ASB rationale was also argued by the Spanish Accounting and Auditing Institute (ICAC, 2005), despite the fact that Spain does not follow an economic substance criterion in its accounting pronouncements. ICAC stated in its comments on IFRIC's interpretations: according to IAS 18 Revenues (paragraph 14), one requirement for recognising revenues from sales is that 'the entity has transferred to the buyer the significant risks and rewards of the ownership of the goods', so, if the grantor is to control the infrastructure, the risk and rewards transferred from the operator to the grantor must be identified together with their link to the control.

The IFRIC definition of assets is consistent with the IASB's Framework and IAS 16 (IASCF, 2008) but, by way of contrast, the Committee on Monetary, Financial and Balance of Payments Statistics (Eurostat, 2004) adopts a risk-based approach. It argues that PPP assets can only be considered non-governmental assets if there is strong evidence that the partner bears most of the risk. This is clarified as meaning that the private sector should bear the construction risk and either the availability or demand risk. 
However, this risk-based policy may indeed lead to complexity and inconsistency since despite the wording that seems to indicate that PPP assets would be government assets, Hall (2005) has argued that in practice these guidelines will facilitate off public sector balance sheet accounting. PwC concur. In their review of the Eurostat rules they $(\mathrm{PwC}$, 2005:61) argue that the EU rules regarding the accounting treatment of PPPs in national accounts are less restrictive than many governments and industry commentators previously feared'. Hall further argues that this is intentional because in principle the EU authorities are in favour of PPPs and see them as a route to enable investment by governments constrained by the EU's own fiscal rules. Furthermore, as PwC (2004b) point out, ESA 95 only covers government accounting from an EU statistical standpoint and so there is no requirement that accounting rules for other purposes should follow suit, raising the prospect that the same asset might appear on different balance sheets, both or none depending on which set of rules are being followed.

Thus, internationally, as in the UK and more recently Spain, accounting regulators appear to be concerned that assets and the associated debts should be recognised on public sector balance sheets. In the private sector off-balance sheet debt has raised concerns about the ability of shareholders to understand the risk to which their company is exposed. Since public debt commits taxpayers to repayment, similar concerns have been raised that the inherent lack of transparency about off-balance sheet financing undermines effective parliamentary scrutiny and democratic control over the use of funds (Pallot, 1992; Newberry and Pallot, 2003; English and Guthrie, 2003).

However, in Spain it is the commercial interests that appear to be in conflict with international accounting regulation. The Spanish toll road sector is concerned about how the IFRIC interpretations will be applied, and how they will be encompassed in the new 
Spanish General Accounting Plan (ASETA 2005). Although the new Plan came into force in 2008, the sectoral variation for the road concessions sector has not yet been replaced by a version which complies with the requirements of international accounting standards. Unsurprisingly the Spanish toll roads sector is hostile to the requirements of IFRIC 12, because compliance is likely to lead to the disappearance of the special accounting treatment for financial expenses, with the effect of creating a barrier against the establishment of new concessionaires, as profits in the early years are affected by high financial expenses being offset against lower turnover. In addition, if the reversion fund is removed, it will affect the economic interest of companies and their shareholders. Already there is evidence that compliance with international accounting standards leads to reductions in both the value of equity and profit for Spanish toll road companies. Table 6 shows the estimated impact of the change in accounting regulation on the only two concessionaires for which comparative figures are available (years 2006 and 2007), with reductions in the value of equity ranging from $20 \%$ to $90 \%$ and in profit ranging from $13 \%$ to $41 \%$. Whilst it is still unclear as to what the impact of applying IFRIC 12 will be on equity and profit, early indications are that the nature of the risk allocation relating to toll roads makes them particularly complex to account for, as under IFRIC 12 they may be categorised as bifurcated assets. This means that the asset may need to be split between an intangible asset arising from the concession agreement and a financial asset arising from the direct user charges. These two factors show why the Spanish road concession sector is reluctant to commit to the accounting requirements introduced by both IFRSs and IFRIC 12.

Insert Table 6 about here 
Although the focus of the regulators' attention has been on actual debt, some commentators have also raised concerns about accounting for contingent liabilities associated with PPPs. These arise because, as PwC (2004a) notes, the private sector will seek to mitigate risk associated with the creditworthiness of parties responsible for future income streams, and subsequently governments have offered guarantees to protect concessionaires' receipts. Especially in relation to emerging and developing economies, the failure to account for these government guarantees renders them invisible but the fear is that multiple guarantees could be triggered simultaneously by an economic crisis, at high cost to the taxpayer (Shaoul et al., 2008). By way of contrast, PwC (2004b) appears to argue against accounting for such guarantees, on the grounds that they do not increase the cost to the public sector, contending (PwC, 2004a: 19) that national government accounting rules should not stand in the way of PPP solutions 'as a result of an inappropriate accounting treatment of guarantees.'

\section{Discussion}

In this section of the paper we examine the implications of the differences in national accounting regulation and then turn to consider the impacts of the change to IFRS. We have shown that there are differences in the national accounting for PPP type projects, because the accounting environment in Spain, a code-law country with a plan-based system, differs from that of the UK, a common law country with a strong capital market. In addition we note that the timing of events has also affected accounting treatment, as in Spain the toll sector developed early, before the development of accounting standards, whilst the opposite has been the case in the UK, with debate on accounting for PPPs taking place after significant development of accounting practices around leasing and reporting the substance of transactions. 
In relation to Spain, where there has been less debate about the accounting treatment of the concession contracts, three points are significant. Firstly, our findings suggest that the Spanish direct toll sector, established prior to the development of an accounting regulatory framework in Spain, has benefited from accounting treatments and other regulations developed to suit its characteristics. These beneficial regulations go further than the lengthy favourable relationship described by Albalate et al. (2009) that exists between the government and the concessionaires. In particular the technical accounting detail surrounding capitalisation of interest provides real economic benefits, especially in the early years of contracts, as expenses are deferred. Secondly, the reversion fund retains funds inside the business until the end of the contract. Whilst this is a mechanism to protect shareholders' capital wealth it may also act as protection for the taxpayer in the event that the road is not in good condition at the end of the contract. We note the irony here that this Spanish legal requirement protects the substance of the project in a way that the UK's accounting treatment may not, as the UK lack of a reversion fund means that the only way to protect the substance of the project is via contractual means, such as escrow accounts. Thirdly in relation to Spain, the government has previously supported this sector by permitting ad hoc asset valuations and providing exchange rate protection, and currently assists the sector by means of participative loans. The economic impact is that the cost of capital is lower for Spanish companies (Acerete et al., 2009). Hence it is not surprising that Spanish infrastructure companies have been expanding throughout Europe and worldwide (Public Works Financing, 2008; Albalate et al., 2009), and thus it is clear that accounting regulation can promote a particular kind of economic activity.

In relation to the UK two points are significant. Firstly, the national regulator has applied influence, based on the accounting principle of substance over form, which has 
resulted in all eight roads we examined being recorded on public sector balance sheet. The benefit of this accounting treatment is the greater transparency in relation to risks for the taxpayer and citizen, although it goes against the original wishes of the Treasury that such PPPs remain off-balance sheet and are thus not part of government debt. However, the Treasury's preferred treatment is in evidence in some regional projects so that it is difficult to compare projects across the UK (Shaoul et al., 2008).

We have argued that Eurostat's interventions may enable an off public sector balance sheet approach, possibly because it follows the continental European accounting model that prefers legal form to substance. As we have argued, this has been the case in Spain where the recognition of assets and debts on the public sector balance sheet did not generate much debate until it became an issue in the context of meeting European Monetary Union convergence criteria. Montesinos and Vela (2000) cite shadow tolling as one example of new funding methods brought in whereby overall debt is not reported on the balance sheet and budgets only reflect the cash payment for the year. This has the effect of deferring payments over a longer period than under traditional procurement. Such a lack of disclosure means that the public cannot easily deduce what the new funding methods are costing. Insofar as these operations represent firm commitments of public expenditure, the public sector should provide information about the total amount of obligations not reflected in the balance sheet, since they are relevant for the establishment of a sustainable tax policy and the capacity for financing and maintaining the level of service delivery (Pina and Torres, 2004).

Secondly, from information made available to investors it is possible to identify guarantees that do not appear in the public sector accounts as contingent liabilities. At this point in time it is unknown whether or not this exclusion is appropriate but there 
have been a number of UK cases where the government has either bailed out or given substantial additional subsidies and grants to PPP type projects, for example, the Royal Armouries Museum, the Channel Tunnel Rail Link and London Underground. There are international parallels. For example, in Australia the government has had to take back under public sector control the La Trobe hospital and the Deer Park PPP prison.

PwC, a major international PPP player, contend that accounting for government guarantees as actual liabilities stands in the way of PPP solutions, and they regard this as unnecessary because 'these do not increase the total cost to the public sectors as a whole' (PwC, 2004a: 19). However, it is interesting that PwC also acknowledge that in many countries, including Spain, such guarantees are accounted for as actual liabilities (PwC 2004a: 19). Since Spain is a major user of private finance, this would suggest that it is not the accounting practice that is reducing the viability of PPPs elsewhere, but rather the probability that there may be a real cost. That is, if PPPs have progressed slowly then the reason may be more about affordability than the absolute size of the long- term liabilities.

Economic globalisation has imposed the need for the international standardisation of accounting. In the case of the EU this need is more intense, because the purpose of making a single market requires the removal of national regulation boundaries, including accounting, to facilitate a free flow of activities. Both Spain and the UK, in common with the rest of the EU, have now adopted accounting standards issued by the IASB so that the future direction of reporting for PPPs will be determined internationally. However, national issues remain. 
The contents of the IFRIC Interpretations have been disputed, from Spain because of commercial interests and from the UK because of the definitions of PPP assets. Many other responses were also critical in nature, for example, the Australian Heads of Treasury Accounting and Reporting Advisory Committee endorsed the UK approach whilst also suggesting further investigation in relation to asset recognition. Despite this, IFRIC 12 implies changes in accounting practice in both the UK and Spain. One impact will be that the UK's shadow toll roads will be accounted for as a financial asset by the private sector, whereas in Spain the intangible asset treatment will mainly be applied. This may not assist inter or intra country comparisons.

In addition, any move to fair value accounting may increase the subjectivity of asset valuations. The IASB's Measurement Bases project has recommended that assets should be valued at fair value (IASB, 2005), and although the IASB has made clear that the intention of its ongoing Fair Value project is to codify and clarify existing fair value accounting, rather than to extend its use (IASB, 2006b), fair value accounting will raise some difficult valuation issues for infrastructure of this nature, especially if the IASB exposure draft, expected in the first quarter of 2010, follows the US position of SFAS 157 Fair Value Measurement by defining fair value in exit price terms.

\section{Conclusion}

Current and future roads investment involves a sizeable proportion of finance from the private sector, $35 \%$ in the UK and $20 \%$ in Spain. This situation is replicated internationally, with worldwide planned PPP spending of $\$ 580$ bn standing at over double the $\$ 265$ bn funded to 2008 (Public Works Financing, 2008). As regards public sector accountability, it is important that taxpayers and citizens are able to hold 
government to account for PPP projects. Financial reporting is an important way of providing some of the necessary information for this accountability.

An important feature of this study is the way in which we probe below the level of the figures given on the face of the relevant financial statements to show the detailed accounting treatment applied to PPPs. Such qualitative analysis is not possible using the data supplied on the relevant companies through the use of databases such as Fame, Amadeus or Thomson One Banker. However it is only through studying the notes to the financial statements for both public and private sector partners that we can discern precisely how the use of private finance is reported and disclosed.

The results show that, prior to the adoption of IFRS, nationally regulated accounting in both public and private sector financial statements in both Spain and the UK lack transparency. Our findings comment explicitly on this, particularly regarding government liabilities and guarantees. In relation to public sector reporting, Spanish cash accounting practices and deferral of expenses in government accounting makes it difficult to determine outcomes, whilst in the UK aggregation and lack of disclosure means that the extent of guarantees is unclear, so that the risks associated with future cash flows are difficult to determine.

The paper also provides evidence from both countries and at EU level that, as the EU implements IFRS and the concessions specific accounting of IFRIC 12, there are three tensions in constant play: technical, political and commercial. In Spain technical accounting currently supports the commercial interests of the concessionaire companies through the provision of unusual accounting regulations, however the requirement to adopt IFRS means that these provisions are likely to cease, leading to conflict with 
commercial interest. In the UK there has been conflict between political choice, which has as its objective the use of private sector finance to provide roads infrastructure, especially major expenditures such as will be involved with the trans-European network, and technical accounting, one objective of which is providing information that enables investors, who in the case of the public sector are the taxpayers, to assess the risk to which they are exposed.

While the uncertainty surrounding accounting for PPPs may have been reduced by the subsequent decisions of the IASB, de jure standardisation of regulation does not always lead to de facto standardisation of accounting practice. At the level of the EU, the requirements of the Maastricht criteria have led to political manoeuvres to permit large scale infrastructure expenditure to go ahead without increasing public debt. The IASB's technical proposals, as they currently stand, are therefore likely to lead to conflict with political objectives. This in turn may have a negative effect on commercial development of TEN-T because of the continuing regulatory barriers around PPPs.

It is our contention that if PPPs are to be extended to fund international infrastructure, for example the massive investments in the TEN-T, then transparency of accounting practice is essential. The valuation of and accounting for associated assets and liabilities is problematical, and failure to account for guarantees as contingent liabilities disguises the risk borne by the tax payer. The technical, political and commercial tensions together with the concerns raised by commentators on IFRIC 12 suggest that the practical application of this complex accounting is worthy of future research. 


\section{References}

Acerete, B., Shaoul, J. and Stafford, A. (2009). 'Taking its toll: the private financing of roads in Spain'. Public Money \& Management, 29(1): 19-26.

AECA (2005). Inmovilizado no Financiero de las Administraciones Públicas. Madrid: Asociación Española de Contabilidad y Administración de Empresas.

Albalate, D. and Bel, G. (2009). 'Regulating concessions of toll motorways: an empirical study on fixed vs. variable term contracts'. Transportation Research Part A, 43: 219-229.

Albalate, D., Bel, G. and Fageda, X. (2009). 'Privatization and regulatory reform of toll motorways in Europe'. Governance: An International Journal of Policy, Administration and Institutions, 22(2): 295-318.

Arnedo, L., Lizarraga, F. and Sánchez, S. (2008). 'Discretionary accruals and auditor behaviour in code-law contexts: An application to failing Spanish firms'. European Accounting Review, 17(4): 641-666.

ASB. (1994). FRS 5 Reporting the Substance of Transactions, Accounting Standards Board, London.

ASB (1998a), Application note F - Private Finance Initiative and Similar Contracts, Accounting Standards Board, London.

ASB (1998b), FRS 12 Provisions, Contingent Liabilities and Contingent Assets, Accounting Standards Board, London.

ASB (2005) Public Comment letter in respect of IFRIC drafts 12, 13 and 14, Accounting Standards Board, available at www.iasb.org

ASC (1984), SSAP 21 Lease and Hire purchase contracts, Accounting Standards Committee, London.

ASETA (2005) Public Comment letter in respect of IFRIC drafts 12, 13 and 14, Asociación Española de Sociedades Concesionarias de Autopistas, Túneles y Puentes de Peaje. Available at www.iasb.org.

Baker, C.R. (2003). 'Investigating Enron as a public private partnership'. Accounting, Auditing and Accountability Journal, 16(3): 446-466.

Bel, G. and Fageda, X. (2005). 'Is a mixed funding model for the highway network sustainable over time? The Spanish case'. In Ragazzi, G., and Rothgatter, W., (eds.), Procurement and Financing Motorways in Europe, Research in Transportation Economics Vol 15, The Netherlands: Elsevier.

Benito, B., Montesinos, V. and Vela, J.M. (2003). 'Local and regional accounting and reporting in Spain: An empirical outlook'. Journal of Public Budgeting, Accounting and Financial Management, Spring, 15(1): 67-91.

Benito, B., Montesinos, V. and Bastida, F. (2008). 'An example of creative accounting in public sector: The private financing of infrastructures in Spain'. Critical Perspectives on Accounting, 19: 963-986.

Broadbent, J. and Laughlin, R., 2003. 'Public Private Partnerships: An Introduction'. Accounting, Auditing and Accountability Journal, 16(3): 332-341.

Cearns, K. (1998). 'PFI accounting amendment goes ahead'. Accountancy, October, 122(1262): 73 
Chen, S., Sun, Z. and Wang, Y. (2002). 'Evidence from China on whether harmonized accounting standards harmonize accounting practices'. Accounting Horizons, 16(3): 183-197 (September).

Choi, F.D.S. and Mueller, G.G. (1992). International Accounting, Englewood Cliffs, NJ: Prentice-Hall.

DETR (2000). Transport 2010: The 10 Year Plan. London: Department of the Environment, Transport and the Regions.

DoT (1993). Paying for Better Motorways. London: Department of Transport.

DoT (1994). Design Build Finance Operate Concessions for Trunk Roads and Motorways. London: Department of Transport.

DTI (2003). DTI Construction Statistics Annual 2002. London: Department of Trade and Industry.

EC (1997). High level group on private financing of Trans-European transport Network projects: final report (Kinnock report). VII/321/97 EN Com (97) 453. Brussels: European Commission.

EC (2001). Opinion of the Economic and Social Committee on the 'Strengthening of the law governing concessions and public/private partnership (PPP) contracts. Brussels: Official Journal of the European Communities 2001/C14/19.

EC (2003a). Guidelines for successful public-private partnerships. Brussels: DG Regional Policy, European Commission.

EC (2003b). High-level group on he trans-European transport network (van Miert Report). Brussels: DG Transport, European Commission.

EC (2004). Public-private partnerships and Community law on public contracts and concessions. Green paper, COM (2004) 327 final. Brussels: European Commission.

Edwards, P., Shaoul, J., Stafford, A. and Arblaster, L. (2004). Evaluating the Operation of PFI in Roads and Hospitals. ACCA Research Report Series, No 84. London: The Certified Accountants Educational Trust (CAET) Ltd.

Engel, E., Fischer, R. and Galetovic, A. (2002). 'A new approach to private roads'. Regulation, Fall: 18-22.

English, L.M. and Guthrie, J. (2003). 'Driving privately financed projects in Australia: what makes them tick? Accounting, Auditing and Accountability Journal, 16(3): 493-511.

Estache, A. (2001). 'Privatization and regulation of transport infrastructure in the 1990s'. The World Bank Research Observer, 16(1): 85-107.

Eurostat (1995) European System of Accounting ESA 1995, European Union, Brussels.

Eurostat (2004). 'New decision of Eurostat on deficit and debt Treatment of publicprivate partnerships, Stat/04/18 11/02/2004 [accessed 21/11/05] http://europa.eu.int/rapid/pressReleases

Farrell, S. (1997). 'Financing European transport infrastructure: policies and practice in Western Europe'. London: Macmillan. 
Financial Reporting Advisory Board (2005). Public Comment letter in respect of IFRIC drafts 12, 13 and 14. Available at www.iasb.org.

Gonzalo, J.A. and Gallizo, J.L. (1992). European Financial Reporting: Spain. London and New York: Routledge.

Grimsey, D. and Lewis, M. (2004). Public Private Partnerships. Cheltenham: Edward Elgar.

Guasch, J.L. (2004). Granting and renegotiating concessions. Doing it right. Washington D.C.: World Bank Institute Development Studies.

Guasch, J.L., Laffont, J.J. and Straub, S. (2005). Concessions of infrastructure in Latin America: Government-led renegotiation. Washington D.C.: World Bank Policy Research Working Paper 3749.

HM Treasury (2008). Accounting for PPP arrangements, including PFI, under IFRS:text for the IFRS-based Financial Reporting Manual (iFReM). Available at http://www.hm-treasury.gov.uk/d/rabig200805.pdf, accessed 26 February 2009.

Hall, D. (2005). PPPs: a critique of the Green Paper. Public Services International Research Unit, www.psiru.org accessed 21/11/05.

Hodge, G. (2004). 'The risky business of public-private partnerships'. Australian Journal of Public Administration, 63(4): 37-49.

IASB (2001). SIC 29 Service Concession Agreements. London: International Accounting Standards Board.

IASB (2005). Measurement Bases: Measurement at Initial Recognition. Discussion Paper led by Institute of Chartered Accountants in Canada. Available at www.iasb.org.

IASB (2006a). IFRIC Interpretation 12. Service Concession Arrangements. Developed by the International Financial Reporting Interpretations Committee and issued by the International Accounting Standards Board. London.

IASB (2006b). Fair Value Measurement. Discussion Paper published for public comment. International Accounting Standards Board. Available at www.iasb.org.

IASC (1989). Framework for the Preparation and Presentation of Financial Statements. London: International Accounting Standards Committee.

IASC (1997). IAS 17 Leases. London: International Accounting Standards Committee.

IASCF (2008) IAS 16 Property, Plant and Equipment (issued 2003, revised 2008). London: International Accounting Standards Committee.

ICAC (1998). Normas de adaptación del Plan General de Contabilidad a las sociedades concesionarias de autopistas. Madrid: Instituto de Contabilidad y Auditoría de Cuentas.

ICAC (2005). Public Comment letter in respect of IFRIC drafts 12, 13 and 14. Instituto de Contabilidad y Auditoría de Cuentas. Available at www.iasb.org.

IPSASB (2008). Accounting and financial reporting for service concession arrangements. International Public Sector Accounting Standards Board. Available at <http://www.ifac.org/Guidance/EXD-Details.php?EDID=0109> accessed 26 February 2009. 
Izquierdo, R. (1997). Gestión y financiación de las infraestructuras de transporte terrestre. Madrid: Asociación Española de la Carretera.

Izquierdo, R. and Vassallo, J.M. (2004). Nuevos sistemas de gestión y financiación de infraestructuras de transporte. Madrid: Asociación Española de la Carretera.

La Porta, R., López-de-Silanes, F., Shleifer, A. and Vishny, R.W. (1997). 'Legal Determinants of external finance', Journal of Finance, 52(3):1131-1150.

Lamb, M., Nobes, C.W. and Roberts, A.D. (1998). 'International Variations in the connections between tax and financial reporting'. Accounting and Business Research, Summer, 28(3): 173-188.

Ministerio de Fomento (various years). Informe sobre el sector de autopistas de peaje en España. Madrid: Centro de Publicaciones Secretaría General Técnica.

Montesinos, V. and Vela, J.M. (2000). 'Governmental accounting in Spain and the European Monetary Union: A critical perspective'. Financial Accountability and Management, 16(2): 129-150.

Newberry, S. and Pallot, J. (2003). 'Fiscal (ir)responsibility: privileging PPPs in new Zealand'. Accounting, Auditing and Accountability Journal, 16(3): 467- 492.

Pallot, J. (1992). 'Elements of a theoretical framework for public sector accounting'. Accounting, Auditing and Accountability Journal, 5(2): 38-59.

Peasnell, K. (1993). 'Accounting in developing countries: A search for appropriate technologies'. Research in Third World Accounting, 2: 1-16.

Pina, V. and Torres, L. (2004). 'Private finance of public infrastructures: shadow toll contracts'. Spanish Journal of Finance and Accounting, Madrid, XXXIII- (123): 935-958.

Pina, V., Torres, L. and Acerete, B. (2003). 'La Iniciativa Privada en el Sector Público: Externalización de Servicios y Financiación de Infraestructuras'. Madrid: AECA.

Public Works Financing (2008).2008 International Survey of Public-Private Partnerships. Volume 231. Westfield, N.J., USA: Public Works Financing.

PwC (2004a). The trans-European transport network: from aspiration to reality. London : PricewaterhouseCoopers.

PwC (2004b). Developing Public Private Partnerships in New Europe. London : PricewaterhouseCoopers.

PwC (2005). Delivering the PPP Promise: A review of PPP issues and activities. London : PricewaterhouseCoopers.

Ramírez, A. and Rojo, A. (2000). 'Implicaciones económicas y financieras del nuevo Plan Sectorial de Autopistas de Peaje'. Actualidad Financiera, 11: 39-62.

Rojo, A. and Ramírez, A. (1999). 'Sociedades concesionarias de autopistas: comentario a las normas de adaptación’. Partida Doble, 104: 62-71.

Shaoul, J., Stafford, A. and Stapleton, P. (2007). 'Partnerships and the role of financial advisors: private control over public policy? Policy and Politics, 35(3): 479-495.

Shaoul, J., Stafford, A., Stapleton, P. and MacDonald, P. (2008). Financial Black Holes: Accounting for Privately Financed Roads in the UK. The Institute of Chartered Accountants of Scotland. 
Standard and Poor's (2003). Public Finance/Infrastructure Finance: Credit Survey of the UK Private Finance Initiative and Public-Private Partnerships. London: Standard and Poor's.

Torres, L. and Pina, V. (2001). 'Public-private partnership and private finance initiatives in the EU and Spanish local governments'. European Accounting Review, 10(3): 601-619.

Torres, L., Pina, V. and Acerete, B. (2003). 'Public-Private Partnerships in Spanish Local Governments'. The European Business Organization Law Review, 4(3): 429-451.

World Bank (1994). World Development Report 1994: Infrastructure for Development. Washington DC: World Bank. 
Table 1: Spanish Toll Roads and Concession Companies

\begin{tabular}{|c|c|c|c|c|}
\hline Concessionaire & Scheme & $\begin{array}{l}\text { Length } \\
\text { (km) }\end{array}$ & $\begin{array}{c}\text { Duration of } \\
\text { concession } \\
\text { (years) }\end{array}$ & Opened to traffic \\
\hline \multicolumn{5}{|l|}{ Roads } \\
\hline \multirow{2}{*}{$\begin{array}{l}\text { Autoestradas de Galicia, SACXG. } \\
\text { (AUTOESTRADAS) }\end{array}$} & AG-55 La Coruña-Carballo & 33 & 50 & $\begin{array}{l}1^{\text {st }} \text {. phase } 1997 \\
2^{\text {nd. }} \cdot \text { phase } 1999\end{array}$ \\
\hline & AG-57 Puxeiros-Bayona & 28 & 50 & 1999 \\
\hline $\begin{array}{l}\text { Autopista Concesionaria Astur- } \\
\text { Leonesa, SA. } \\
\text { (AUCALSA) }\end{array}$ & AP-66 León-Campomanes & 78 & 75 & $\begin{array}{l}1^{\text {st }} \text { phase } 1983 \\
2^{\text {nd }} \text { phase } 1997\end{array}$ \\
\hline \multirow{2}{*}{$\begin{array}{l}\text { Autopista del Sol, CESA. } \\
\text { (AUSOL) }\end{array}$} & AP-7 Málaga-Estepona & 83 & 50 & 1999 \\
\hline & AP-7 Estepona-Guadiaro & 22 & 55 & 2002 \\
\hline $\begin{array}{l}\text { Autopista del Sureste, CEASA. } \\
\text { (SURESTE) }\end{array}$ & AP-7 Alicante-Cartagena & 77 & 50 & 2001 \\
\hline $\begin{array}{l}\text { Autopista Terrasa-Manresa, SACGC. } \\
\text { (AUTEMA) }\end{array}$ & E-9/C-16 San Cugat-Manresa & 43 & 50 & 1991 \\
\hline $\begin{array}{l}\text { Autopista Vasco-Aragonesa, CESA. } \\
\text { (AVASA) }\end{array}$ & AP-68 Bilbao-Zaragoza & 29 & 53 & \\
\hline \multirow{3}{*}{$\begin{array}{l}\text { Autopistas Aumar, SACE. } \\
\text { (AUMAR) }\end{array}$} & AP-4 Sevilla-Cádiz & 94 & 50 & 1972 \\
\hline & AP-7 Tarragona-Valencia & 225 & 48 & 1974 \\
\hline & AP-7 Valencia-Alicante & 149 & 47 & 1974 \\
\hline \multirow{5}{*}{$\begin{array}{l}\text { Autopistas CESA. } \\
\text { (ACESA.) }\end{array}$} & AP-7 Barcelona-La Junquera & 150 & 54 & 1975 \\
\hline & C-32 Montgat-Palafolls & 49 & 54 & 1969 \\
\hline & AP-7 Barcelona-Tarragona & 110 & 53 & 1974 \\
\hline & AP-2 Zaragoza-Mediterráneo & 215 & 48 & 1977 \\
\hline & AP-7 Montmeló -El Papiol & 27. & 47 & 1978 \\
\hline $\begin{array}{l}\text { Autopistas de Cataluña, S.A. } \\
\text { (AUCAT) }\end{array}$ & C-32 Castelldefels-El Vendrell & 50 & 50 & $\begin{array}{l}1^{\text {st }} \text { phase } 1992 \\
2^{\text {nd }} \text { phase } 1998\end{array}$ \\
\hline $\begin{array}{l}\text { Autopistas de León, SACE } \\
\text { (AULESA) }\end{array}$ & AP-71 León-Astorga & 38 & 55 & 2002 \\
\hline $\begin{array}{l}\text { Autopistas de Navarra, SACE } \\
\text { (AUDENASA) }\end{array}$ & A-15 Tudela-Izurzun & 113 & 56 & $\begin{array}{c}1^{\text {st. }} \text { phase } 1976 \\
2^{\text {nd }} . \text { phase } 1980\end{array}$ \\
\hline $\begin{array}{l}\text { Autopistas del Atlántico CESA. } \\
\text { (AUDASA) }\end{array}$ & AP-9 Ferrol-Frontera Portugal & 219 & 75 & $\begin{array}{l}1^{\text {st }} \text { phase } 1979 \\
\text { (different phases } \\
\text { until 2003) }\end{array}$ \\
\hline \multirow{2}{*}{$\begin{array}{l}\text { Castellana de Autopistas, SACE } \\
\text { (CASTELLANA) }\end{array}$} & AP-51 Ávila-Villacastín & 23 & $32-37$ & 2002 \\
\hline & AP-61 Segovia San-Rafael & 28 & $32-37$ & 2003 \\
\hline Europistas, CESA. (EUROPISTAS) & AP-1 Burgos-Armiñón & 84 & 43 & 1971 \\
\hline $\begin{array}{l}\text { Iberpistas, SACE } \\
\text { (IBERPISTAS) }\end{array}$ & AP-6 Villalba-Adanero & 70 & $63-68$ & $\begin{array}{c}1^{\text {st }} \text { phase } 1972 \\
2^{\text {nd }} \text { phase } 1976\end{array}$ \\
\hline $\begin{array}{l}\text { Accesos de Madrid, CESA. } \\
\text { (AM) }\end{array}$ & $\mathrm{R}-3, \mathrm{R}-5, \mathrm{M} 50$ & 92 & 50 & 2003 \\
\hline $\begin{array}{l}\text { Autopista Central Gallega, CESA. } \\
\text { (ACEGA) }\end{array}$ & AP-53 & 57 & 75 & 2002 \\
\hline $\begin{array}{l}\text { Autopista del Henares, CESA. } \\
\text { (HENARSA) }\end{array}$ & $\mathrm{R}-2, \mathrm{M}-50$ & 86 & 25 & 2003 \\
\hline $\begin{array}{l}\text { Autopista Madrid-Sur, CESA. } \\
\text { (AUMASUR) }\end{array}$ & R-4, M-50 (M-409 - A-2), M-31 & 99 & 65 & 2004 \\
\hline $\begin{array}{l}\text { Autopista Costa Cálida, CESA. } \\
\text { (AUCOSTA) }\end{array}$ & AP-7 & 114 & $36-40$ & 2007 \\
\hline $\begin{array}{l}\text { Autopista Madrid-Levante, CESA. } \\
\text { (AUMALESA) }\end{array}$ & AP-36 & 177 & $36-40$ & 2006 \\
\hline Autopista Madrid-Toledo, CESA. & AP-41 & 81 & $36-40$ & 2007 \\
\hline CIRALSA, SACE & AP-7 Circunvalación Alicante & 54 & $36-40$ & 2007 \\
\hline Autopista Eje-Aeropuerto & M-12 & 9 & 25 & 2001 \\
\hline
\end{tabular}

Source: Ministry of Public Works

Asociacion Española de Empresas Concesionarias de Autopistas, Tuneles y Otras Vias de Peaje (ASETA) 
Table 2: Spanish Shadow Toll Roads and Concession Companies

\begin{tabular}{|l|l|c|c|c|}
\hline \multicolumn{1}{|c|}{ Concessionaire } & \multicolumn{1}{|c|}{ Scheme } & $\begin{array}{c}\text { Length } \\
(\mathbf{k m})\end{array}$ & $\begin{array}{c}\text { Duration of } \\
\text { concession } \\
\text { (years) }\end{array}$ & Opened to traffic \\
\hline Autovía del Noroeste, SCCARM & Alcantarilla-Caravaca & 60 & 27 & 2001 \\
\hline Concesiones de Madrid, SA & M-45 N II-Eje O'Donnell & 14 & 34 & 2002 \\
\hline Euroglosa 45, SA & M-45 N IV - N V & 8 & 29 & 2002 \\
\hline Ruta de los Pantanos, SA & M-501 \& M-511 & 22 & 25 & 2002 \\
\hline Trados 45, SA & M-45 Eje O'Donnell-N IV & 15 & 31 & 2002 \\
\hline Aumancha, SA & Autovía de la Mancha & 52 & 30 & 2005 \\
\hline Autovía del Camino, SCSA & Pamplona-Logroño & 70 & 30 & 2006 \\
\hline Concesionaria Madrid 407 & M-407 & 12 & 30 & 2007 \\
\hline El Burgo-Villafranca & N-232- AP-II & 5 & 30 & 2007 \\
\hline Turia, SCSA & Autovía del Turia & 53 & 35 & 2008 \\
\hline Eresma, SCSA & Autovía del Eresma & 49 & 35 & 2008 \\
\hline Barbanza, SCSA & Autovía del Barbanza & 40 & 30 & 2008 \\
\hline Aupisa, SA & Autovía de los Pinares & 43 & 35 & 2008 \\
\hline Concesionaria Santiago-Brión & Santiago-Brión & 15 & 30 & 2008 \\
\hline Reus-Alcover, SCSA & Reus-Alcover & 10 & 33 & 2008 \\
\hline
\end{tabular}

Source: Ministry of Public Works

Asociacion Española de Empresas Concesionarias de Autopistas, Tuneles y Otras Vias de Peaje (ASETA) 
Table 3 UK PPP Shadow Toll Schemes

\begin{tabular}{|c|c|c|c|c|}
\hline \multicolumn{5}{|c|}{ Highway Agency Schemes } \\
\hline \multicolumn{5}{|c|}{ Tranche 1} \\
\hline Scheme & $\begin{array}{l}\text { Contract } \\
\text { Award }\end{array}$ & DBFO Co & $\begin{array}{l}\text { Capital } \\
\text { Cost } \\
(£ \mathrm{~m})\end{array}$ & $\begin{array}{c}\text { Length }(\mathrm{km}) \text { and } \\
\text { Summary description }\end{array}$ \\
\hline A69 Newcastle-Carlisle & $1 / 96$ & Road Link Ltd & 9 & $\begin{array}{c}84 \mathrm{~km} \\
\text { Construct } 3.5 \mathrm{~km} \text { by-pass }\end{array}$ \\
\hline $\begin{array}{l}\text { A1(M) Alconbury- } \\
\text { Peterborough }\end{array}$ & $2 / 96$ & $\begin{array}{l}\text { Road Management } \\
\text { Services Ltd }\end{array}$ & 128 & Motorway widening $21 \mathrm{~km}$ \\
\hline $\begin{array}{l}\text { A417/A419 Swindon- } \\
\text { Gloucester }\end{array}$ & $2 / 96$ & $\begin{array}{l}\text { Road Management } \\
\text { Services Ltd }\end{array}$ & 49 & $\begin{array}{l}52 \mathrm{~km} \\
3 \text { new sections of road }\end{array}$ \\
\hline M1-A1 Motorway Link & $3 / 96$ & Yorkshire Link Ltd & 214 & $\begin{array}{l}\text { New motorway, } \\
\text { motorway widening and } \\
\text { new interchange }\end{array}$ \\
\hline \multicolumn{5}{|c|}{ Tranche 1A } \\
\hline $\begin{array}{l}\text { A50/A564 Stoke-Derby } \\
\text { Link }\end{array}$ & $5 / 96$ & Connect Ltd & 21 & $\begin{array}{c}57 \mathrm{~km} \\
\text { Construct } 5.2 \mathrm{~km} \text { by-pass }\end{array}$ \\
\hline A30/A35 Exeter-Bere Regis & $7 / 96$ & Connect Ltd & 75 & $\begin{array}{l}102 \mathrm{~km} \\
\text { Construct } 2 \text { new sections } \\
\text { and 9km bypass }\end{array}$ \\
\hline M40 Denham-Warwick & $10 / 96$ & UK Highways Ltd & 65 & $\begin{array}{l}122 \mathrm{~km} \\
\text { Motorway widening }\end{array}$ \\
\hline $\begin{array}{l}\text { A168/19 Dishforth-Tyne } \\
\text { Tunnel }\end{array}$ & $10 / 96$ & $\begin{array}{l}\text { Autolink } \\
\text { Concessionaires (A19) }\end{array}$ & 29 & $\begin{array}{l}118 \mathrm{~km} \\
\text { On line widening }\end{array}$ \\
\hline \multicolumn{5}{|c|}{ Tranche 2} \\
\hline A13 Thames Gateway* & $4 / 00$ & $\begin{array}{l}\text { Road Management } \\
\text { Services Ltd }\end{array}$ & 146 & $\begin{array}{l}\text { On line upgrade and } \\
\text { improvement schemes }\end{array}$ \\
\hline A1 Darrington-Dishforth & $9 / 02$ & $\begin{array}{l}\text { Road Management } \\
\text { Services Ltd }\end{array}$ & 210 & $\begin{array}{l}\text { Construct } 2 \text { new sections } \\
\text { of motorway and } \\
\text { communications }\end{array}$ \\
\hline $\begin{array}{l}\text { A249 Stockbury to } \\
\text { Sheerness }\end{array}$ & $02 / 04$ & Sheppey Route Ltd & 73 & $\begin{array}{l}17 \mathrm{~km} \\
\text { Road linking the M2 and } \\
\text { Sheerness Docks }\end{array}$ \\
\hline \multicolumn{5}{|c|}{ Scottish Office Schemes } \\
\hline M6/A74 & $12 / 96$ & $\begin{array}{l}\text { Autolink } \\
\text { Concessionaires (M6) }\end{array}$ & 96 & $\begin{array}{l}90 \mathrm{~km} \\
\text { Construct new sections of } \\
\text { motorway and trunk road }\end{array}$ \\
\hline M77 & $04 / 03$ & Connect M77/GSO plc & 130 & $\begin{array}{l}\text { Extension to motorway } \\
\text { and new A road }\end{array}$ \\
\hline \multicolumn{5}{|c|}{ Welsh Office Schemes } \\
\hline A55 Llandegai-Holyhead & $12 / 98$ & UK Highways Ltd & 120 & $\begin{array}{l}50 \mathrm{~km} \\
\text { Construct section of trunk } \\
\text { road }\end{array}$ \\
\hline \multicolumn{5}{|c|}{ Northern Ireland Executive } \\
\hline Roads Service DBFO Pack 1 & $02 / 06$ & $\begin{array}{l}\text { Highway Management } \\
\text { (City) Ltd }\end{array}$ & 118 & $\begin{array}{l}\text { Upgrade to M1 \& M2 } \\
\text { including Westlink in } \\
\text { Belfast }\end{array}$ \\
\hline Roads Service DBFO Pack 2 & $12 / 07$ & Amey Lagan Roads & 224 & $\begin{array}{l}\text { Roads improvements to } \\
\text { A1 and A4/A5 }\end{array}$ \\
\hline \multicolumn{5}{|c|}{ Local Authority Schemes } \\
\hline A130 (A12-A127) & $10 / 99$ & County Route & 75 & $\begin{array}{l}15 \mathrm{~km} \\
\text { Construct section of trunk } \\
\text { road }\end{array}$ \\
\hline $\begin{array}{l}\text { Newport Southern } \\
\text { Distributor Road }\end{array}$ & $6 / 02$ & Morgan Vinci & 50 & New river crossing $9.3 \mathrm{~km}$ \\
\hline SEW Road & $01 / 04$ & $\begin{array}{l}\text { Sirhowy Enterprise Way } \\
\text { Ltd }\end{array}$ & 57 & $\begin{array}{r}\text { DBFO of SEW, } \\
\text { Caerphilly }\end{array}$ \\
\hline
\end{tabular}

Sources: Department of Trade and Industry: Construction Statistics Annual 2002, Department for Transport, PPP

Forum, HM Treasury PFI Statistics, Partnerships UK

Note: * In July 2000, project responsibility passed from Highways Agency to Transport for London 
$\underline{\text { Table } 4 \text { UK and Spain PPP Framework }}$

\begin{tabular}{|c|c|}
\hline \multicolumn{2}{|c|}{ ACCOUNTING REGULATORY ENVIRONMENT } \\
\hline UK & SPAIN \\
\hline Common law system & Code-law system \\
\hline $\begin{array}{l}\text { Self-regulating accounting profession that issues } \\
\text { accounting standards }\end{array}$ & Plan-based financial reporting issued by a public body \\
\hline Strong equity capital market (investor protection) & Credit as main financial system (creditors protection) \\
\hline Separation of tax and financial tax and accounting & Tax dominated accounting system \\
\hline \multicolumn{2}{|c|}{ CHARACTERISTICS OF PPP ROADS SECTOR } \\
\hline UK & SPAIN \\
\hline Starting date: $1990 \mathrm{~s}$ & Starting date: $1960 \mathrm{~s}$ \\
\hline $\begin{array}{l}\text { Shadow toll model, more recently performance } \\
\text { mechanism and direct tolls }\end{array}$ & $\begin{array}{l}\text { Direct toll model, more recently shadow tolls } \\
\text { (autonomous governments) }\end{array}$ \\
\hline $\begin{array}{l}\text { Coordination and management by public agency } \\
\text { (Partnerships UK) }\end{array}$ & No equivalent \\
\hline $\begin{array}{l}\text { Private operators constituted in 'special purpose } \\
\text { vehicles' set up by consortia }\end{array}$ & $\begin{array}{l}\text { Operators are public limited companies (set up by / } \\
\text { subsidiaries of construction companies) }\end{array}$ \\
\hline
\end{tabular}


Table 5 Comparison of Accounting Approaches

\begin{tabular}{|c|c|c|}
\hline SPAIN & UK & IFRIC \\
\hline \multicolumn{3}{|c|}{ BASIS OF ACCOUNTING TREATMENT } \\
\hline $\begin{array}{l}\text { Code-law regime: legal and tax } \\
\text { implications. }\end{array}$ & $\begin{array}{l}\text { Economic substance over legal } \\
\text { form of transactions. }\end{array}$ & $\begin{array}{l}\text { PPP Assets and liabilities defined } \\
\text { according to control }\end{array}$ \\
\hline \multicolumn{3}{|c|}{ ACCOUNTING DEBATE } \\
\hline $\begin{array}{l}\text { There has been minimum debate. } \\
\text { Spanish accounting treatment of } \\
\text { infrastructure and contracts fits } \\
\text { with EMU public deficit and debt } \\
\text { requirements. There is no } \\
\text { consideration of the economic } \\
\text { rationale of transactions. }\end{array}$ & $\begin{array}{l}\text { Much debate between accounting } \\
\text { regulator and Treasury about the } \\
\text { nature of PPP, which leads to } \\
\text { competing views of where the } \\
\text { asset in PPPs lies. }\end{array}$ & $\begin{array}{l}\text { Pronouncements try to determine } \\
\text { how the details of the contract are } \\
\text { interpreted within the control based } \\
\text { definitions. }\end{array}$ \\
\hline \multicolumn{3}{|c|}{ ACCOUNTING REGULATION } \\
\hline $\begin{array}{l}\text { Specific accounting variation to } \\
\text { the Spanish General Accounting } \\
\text { Plan for the toll sector. }\end{array}$ & $\begin{array}{l}\text { PPPs accounting followed } \\
\text { existing regulations on leasing } \\
\text { and substance over form with } \\
\text { modifications. }\end{array}$ & $\begin{array}{l}\text { Evolution of applicable regulation } \\
\text { from leases, going through disclosure } \\
\text { requirements, to specific accounting } \\
\text { treatment provided by IFRIC's } \\
\text { interpretations. }\end{array}$ \\
\hline \multicolumn{3}{|c|}{ ACCOUNTING ISSUES and ACCOUNTABILITY CONSEQUENCES } \\
\hline $\begin{array}{l}\text { Capitalisation of financial } \\
\text { expenses once the motorway is } \\
\text { opened to traffic as deferred } \\
\text { expenditure: becoming } \\
\text { mechanism for new } \\
\text { concessionaires. }\end{array}$ & $\begin{array}{l}\text { Separability of service and } \\
\text { property elements of contract: } \\
\text { infrastructure-based service(off } \\
\text { public balance sheet) or financing } \\
\text { arrangement (on public balance } \\
\text { sheet). }\end{array}$ & $\begin{array}{l}\text { Infrastructures falling within the } \\
\text { definition of a service concession } \\
\text { arrangement should not be } \\
\text { recognised as property, plant and } \\
\text { equipment in operator's Balance } \\
\text { sheets. A rebuttable assumption that } \\
\text { asset would be on public balance } \\
\text { sheet. }\end{array}$ \\
\hline $\begin{array}{l}\text { Creation of a 'reversion fund': } \\
\text { protection of investors' funds } \\
\text { (may also protect taxpayers' } \\
\text { funds). }\end{array}$ & $\begin{array}{l}\text { Party that bears the risks and } \\
\text { rewards of ownership (eg } \\
\text { potential variations in property } \\
\text { profits and losses) is the party } \\
\text { having an asset. }\end{array}$ & $\begin{array}{l}\text { Financial and intangible asset models } \\
\text { used depending on whether the } \\
\text { primary responsibility to pay the } \\
\text { operator lies with the grantor or } \\
\text { service user. }\end{array}$ \\
\hline $\begin{array}{l}\text { Ad hoc revaluations: to increase } \\
\text { the value of assets and facilitate } \\
\text { access to finance. }\end{array}$ & $\begin{array}{l}\text { Asymmetrical reporting between } \\
\text { public and private agents: } \\
\text { taxpayers face uncertainty about } \\
\text { future liabilities. }\end{array}$ & $\begin{array}{l}\text { The accounting model is based on } \\
\text { formal criteria, not on the economic } \\
\text { substance of transactions: similar } \\
\text { arrangements may be accounted for } \\
\text { differently. }\end{array}$ \\
\hline $\begin{array}{l}\text { Public support (exchange rate } \\
\text { insurance, subsidies, refundable } \\
\text { advance payments, participative } \\
\text { loans): boundaries between } \\
\text { public and private sector become } \\
\text { blurred. }\end{array}$ & $\begin{array}{l}\text { Annual tariffs may be split into } \\
\text { two parts in the income statement } \\
\text { and in the balance sheet: lack of } \\
\text { comparability since companies } \\
\text { may vary their recognition policy. }\end{array}$ & $\begin{array}{l}\text { IASB's pronouncements relate to } \\
\text { private sector companies. IFRICs } \\
\text { exclude accounting for public sector } \\
\text { grantors. Much criticised by } \\
\text { commentators. }\end{array}$ \\
\hline $\begin{array}{l}\text { Not all public support } \\
\text { mechanisms are adequately } \\
\text { reflected in public accounts: } \\
\text { taxpayers face uncertainty about } \\
\text { future liabilities. }\end{array}$ & $\begin{array}{l}\text { Government's guarantees of } \\
\text { Highways Agency's payments are } \\
\text { not reflected in the public sector } \\
\text { accounts: taxpayers face } \\
\text { uncertainty about future } \\
\text { liabilities. }\end{array}$ & $\begin{array}{l}\text { The scope of IFRIC's interpretations } \\
\text { is based on the control criteria. } \\
\text { Eurostat uses an approach based on } \\
\text { assessment of where risk lies for } \\
\text { statistical purposes. The outcomes } \\
\text { may vary. }\end{array}$ \\
\hline
\end{tabular}

Sources: Examination of the notes to the financial statements of companies listed in Tables 1,2 \&3, plus summary of accounting regulations and other commentaries. 
Table 6 Estimates of impact of IAS on two Spanish concessionaires

\begin{tabular}{|c|c|c|c|c|c|c|c|c|c|c|c|c|}
\hline & \multicolumn{6}{|c|}{ AVASA } & \multicolumn{6}{|c|}{ AUDASA } \\
\hline & \multirow{2}{*}{\multicolumn{3}{|c|}{$\begin{array}{l}\text { Equity } \\
€^{\prime} 000\end{array}$}} & \multirow{2}{*}{\multicolumn{3}{|c|}{$\begin{array}{l}\text { P\&L } \\
€ ' 000\end{array}$}} & \multirow{2}{*}{\multicolumn{3}{|c|}{$\begin{array}{l}\text { Equity } \\
€^{\prime} 000\end{array}$}} & \multirow{2}{*}{\multicolumn{3}{|c|}{$\begin{array}{l}\text { P\&L } \\
€^{\prime} 000\end{array}$}} \\
\hline & & & & & & & & & & & & \\
\hline Year & Actual & $\begin{array}{c}\text { Estimate } \\
\text { under IAS }\end{array}$ & Var. & Actual & $\begin{array}{c}\text { Estimate } \\
\text { under IAS }\end{array}$ & Var. & Actual & $\begin{array}{c}\text { Estimate } \\
\text { under IAS }\end{array}$ & Var. & Actual & $\begin{array}{c}\text { Estimate } \\
\text { under IAS }\end{array}$ & Var. \\
\hline 2006 & 286,670 & 51,101 & $-82 \%$ & 56,382 & 43,411 & $-23 \%$ & 439,330 & 348,675 & $-20 \%$ & 51,0222 & 36,976 & $-27 \%$ \\
\hline 2007 & 289,231 & 27,054 & $-90 \%$ & 75,820 & 44,623 & $-41 \%$ & 442,879 & 342,137 & $-22 \%$ & 56,469 & 48,897 & $-13 \%$ \\
\hline
\end{tabular}

Source: Notes to the annual reports and accounts, 2007 